\title{
B cell Semaphorin 4c expression mitigates the airway hyperresponsiveness and acute inflammation which characterize allergic airway disease
}

\author{
Alex Lei ${ }^{1^{*}}$, Di Xue ${ }^{1}$, Marylin Desjardins ${ }^{1}$, Marianne Beland ${ }^{1}$, Bruce Mazer ${ }^{1,2}$ \\ From Canadian Society of Allergy and Clinical Immunology Annual Scientific Meeting 2014 \\ Ottawa, ON, Canada. 23-26 October 2014
}

\section{Background}

Semaphorin signaling proteins, initially examined in the context of neuronal axon development, have recently been implicated as regulators of immune cell migration. Our laboratory has determined that expression of Semaphorin $4 \mathrm{C}$ (Sema4C) is strongly induced on B cells exposed to Th2 stimulation, and we seek to elucidate its mechanism of controlling allergic airway disease.

\section{Methods}

Wild-type and Sema $4 \mathrm{C}^{-/-}$mice were sensitized intraperitoneally using $100 \mu \mathrm{L}$ OVA $(0.5 \mathrm{mg} / \mathrm{mL}$ ovalbumin and 4 $\mathrm{mg} / \mathrm{mL}$ aluminum hydroxide in PBS) on days 0 and 14 , and were challenged intranasally using $20 \mu \mathrm{L}$ OVA (10 $\mathrm{mg} / \mathrm{mL}$ ovalbumin in PBS) from days 28 to 30 . Sacrifice and analysis of Airway Hyperresponsiveness via flexiVent was performed on day 31. Serum IgE and IL-10 expression levels were measured by ELISA. B cells were phenotyped by fluorescence-activated cell sorting (FACS). B cell motility was measured by migration assays.

\section{Results}

Please see figure 1.

\section{Conclusions}

Semaphorin $4 \mathrm{C}$ regulates the allergic airway disease through immune synapse-governed cytoskeletal rearrangements in $\mathrm{B}$ cells, and minimizes the inflammatory cellular lung infiltration that contributes to airway hyperresponsiveness.

\author{
Authors' details \\ ${ }^{1}$ Meakins-Christie Laboratories, Department of Experimental Medicine, McGill \\ University, Montreal, Quebec, H2X 2P2, Canada. ${ }^{2}$ Montreal Children's \\ Hospital, Department of Pediatrics, McGill University Health Center, Montreal, \\ Quebec, H3H 1P3, Canada.
}

Published: 18 December 2014

doi:10.1186/1710-1492-10-S2-A26

Cite this article as: Lei et al:: B cell Semaphorin 4c expression mitigates the airway hyperresponsiveness and acute inflammation which characterize allergic airway disease. Allergy, Asthma and Clinical Immunology 2014 10(Suppl 2):A26.
Submit your next manuscript to BioMed Central and take full advantage of:

- Convenient online submission

- Thorough peer review

- No space constraints or color figure charges

- Immediate publication on acceptance

- Inclusion in PubMed, CAS, Scopus and Google Scholar

- Research which is freely available for redistribution
() Biomed Central 


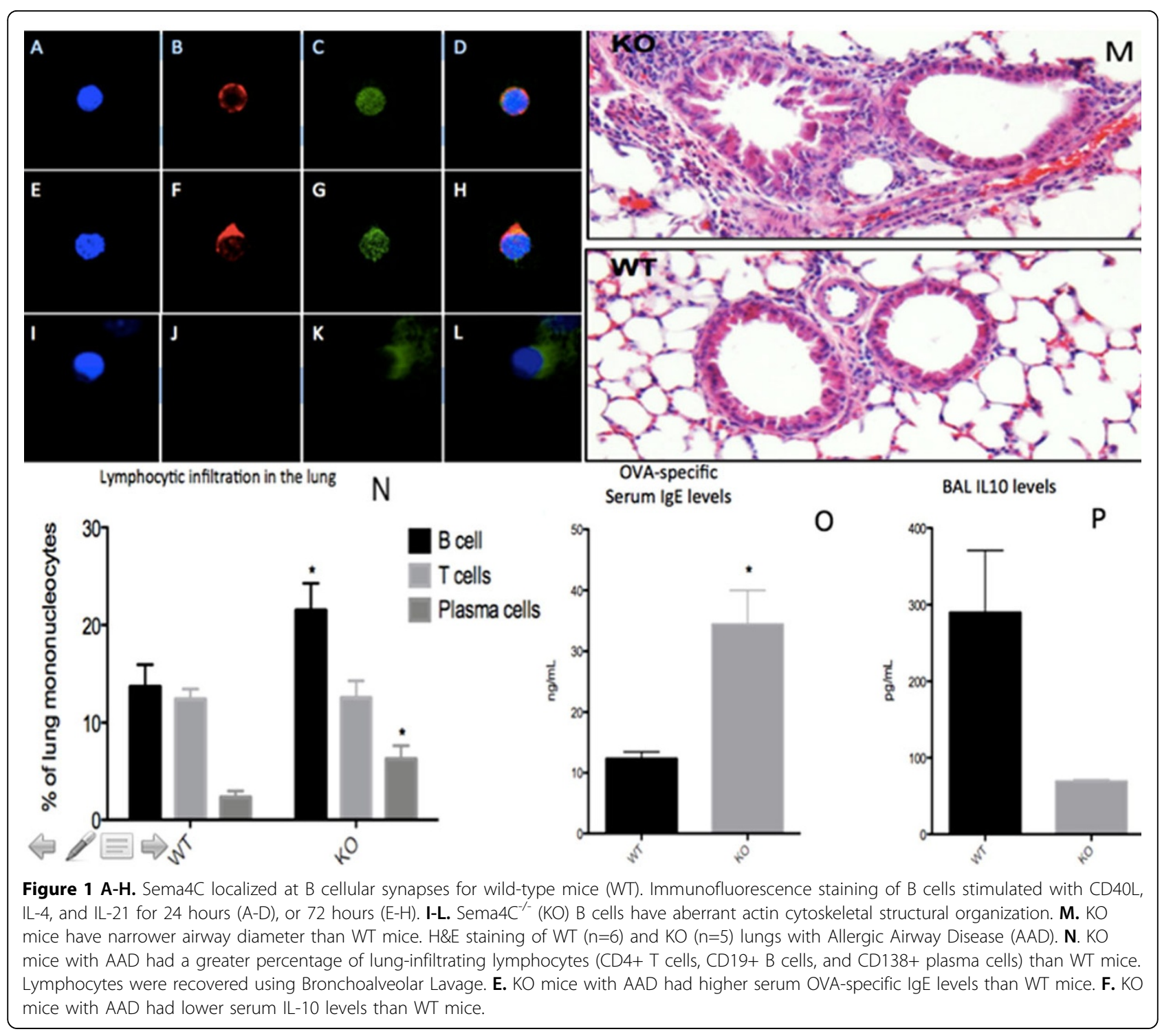

